\title{
MORPHOGENESIS OF CONTRACAECUM RUDOLPHII (Nematoda: AscaridoIdeA), A PARASITE Of FISH-EATING BIRDS, IN ITS COPEPOD PRECURSOR AND FISH INTERMEDIATE HOSTS
}

\author{
BARTLETT C.M.*
}

\section{Summary :}

Eggs of Contracaecum rudolphii obtained from female worms in double-crested cormorants (Phalacrocorax auritus) in Nova Scotia Canada, hatched in 9-17 days in sea water at $15-20^{\circ} \mathrm{C}$. The newly-emerged, free-living (and presumably second-stage) larva is described in detail, as are larvae from experimentally-infected copepods (Tigriopus sp.), amphipods (Gammarus sp.), and fish (Lebistes reticulatus, Fundulus heteroclitus). Copepods are considered precursor hosts and morphogenesis of the parasite in them primarily involved body size, the ventricular appendix, and the excretory system. Infection of amphipods and fish was much more successful when invading larvae were from copepods than when they were free living; amphipods served as paratenic hosts and fish as intermediates. In fish, second-stage larvae 20 or fewer days postinfection were within the intestinal wall. At 44 or more days postinfection, larvae were considered third stage; all were in the abdominal cavity, many within a closely adhering "sleeve " of material resembling cuticle. The longest larvae (3.1-3.9 mm) in fish were associated with the oldest infection (152 d), suggesting that larvae continue to grow for a considerable period of time; growth was also found to be asynchronous, however.

KEY WORDS : nematode, parasite, Contracaecum spiculigerum, Ascaridoidea morphogenesis, intermediate, paratenic, cormorant, bird.

\section{INTRODUCTION}

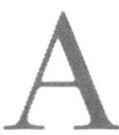
scaridoid nematodes, common parasites of the stomach or intestines of vertebrates, are often rather plastic with respect to transmission (Anderson 1992). Contracaecum rudolphii Hartwich, 1964, for example, undergoes " partial development " in copepods followed by later development in fish to the stage infective to the avian final host (e.g. cormorants, Phalacrocorax spp.) (Huizinga 1966) (note: Hartwich (1964) proposed C. rudolphii as a new name for the Contracaecum sp. found mainly in cormorants; Huizinga (1966) referred to his specimens as Contracaecum spiculigerum). However, fish can also be infected directly, i.e. without the agency of copepods (Huizinga 1966), suggesting development in

\footnotetext{
* Biology, University College of Cape Breton, PO Box 5300, Sydney, Nova Scotia, Canada B1P 6L2.

Phone: 902-563-1624 - Fax: 902-562-0119 - e-mail: cbartlet@sparc.uccb.ns.ca.
}

Résumé : MORPHOGENÈse de CONTRACAECUM RUDOLPHII

(Nematoda : Ascaridoidea), parasite des oiseaux DE MER, CHEZ SON HÔTE PRÉCURSEUR, LE COPÉPODE, ET SON HÔTE INTERMÉDIAIRE, LE POISSON

La larve de deuxième stade de Contracaecum rudolphii, de connaissance récente et vivant sans hôte, est décrite en détail ainsi que les larves venant de copépodes infectés en laboratoire (Trigriopus sp.), d'amphipodes (Gammarus sp.) et de poissons (Lebistes reticulatus, Fundulus heteroclitus). La morphogenèse du parasite dans le copépode, considéré comme hôte précurseur, inclut la taille, l'appendice ventriculaire et le système excrétoire. L'infection des amphipodes et des poissons est beaucoup plus importante lorsque les larves proviennent des copépodes que lorsqu'elles vivent sans hôte; les amphipodes ont servi d'hôtes paraténiques et le poisson d'hôte intermédiaire. Chez le poisson, les larves ont atteint le troisième stade 44 jours ou plus après l'infection; toutes se trouvaient dans la cavité abdominale, plusieurs à l'intérieur d'un "sac "étroitement ajusté et d'un matériau évoquant une cuticule. Chez le poisson, les larves les plus longues mesuraient de 3,1 à 3,9 mm (152 d). Il est probable que les larves continuent à grandir chez le poisson pendant une longue période mais la croissance en est cependant asynchrone.

MOTS CLÉS : nématode, parasite, Contracaecum spiculigerum, Ascaridoidea, morphogenèse, intermédiaire, paraténique, cormoran, oiseau.

copepods may be trivial. The present study sought to clarify our understanding of these events through a detailed examination of the parasite's morphology in copepods, amphipods, and fish. It worked from the premise of Huizinga (1966) that a second-stage larva emerges from the egg of C. rudolphii (although studies on related species [e.g. Køie and Fagerholm 1993; Measures and Hong 1995] suggest this requires re-examination using transmission electron microscopy). Morphogenesis occurred in both copepods and fish, enabling their designation as precursor and intermediate hosts, respectively.

\section{METHODS AND MATERIALS}

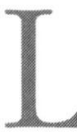

ive females of C. rudolphii were removed from the proventriculus of double-crested cormorants (Phalacrocorax auritus) shot on Delorier Island $\left(45^{\circ} 31^{\prime} \mathrm{N}, 61^{\circ} 06^{\prime} \mathrm{W}\right)$ near Arichat or on Red Islands $\left(45^{\circ} 48^{\prime} \mathrm{N}, 60^{\circ} 46^{\prime} \mathrm{W}\right)$ near Johnstown, Nova Scotia, 
Canada, in June and July, 1992 and 1993. Eggs were dissected from females and incubated at $10^{\circ}, 15^{\circ}$, and $20^{\circ} \mathrm{C}$ in Syracuse dishes $(4 \times 4 \mathrm{~cm})$ containing sea water that had been passed through a millepore filter (0.47 $\mu \mathrm{m}$ grid size).

Once larvae hatched, various experiments (outlined below) were conducted. Copepods (Tigriopus sp.), amphipods (Gammarus sp.), and larval fish (mummichog, Fundulus heteroclitus, $0.75-1,25 \mathrm{~cm}$ long) used in the experiments were collected in a tidal marsh near Port Morien $\left(46^{\circ} 08^{\prime} \mathrm{N}, 59^{\circ} 52^{\prime} \mathrm{W}\right)$ ), Nova Scotia (note: 50 copepods, 50 amphipods, and 50 larval mummichog were also examined as controls; nematode larvae were not present). Guppies (Lebistes reticulatus) were purchased from a local pet store.

Experiments A-C exposed recently-emerged larvae to copepods (A), amphipods (B), and fish (C). Hundreds of larvae were placed in filtered water in each of numerous Syracuse dishes and then dozens of copepods, four amphipods, or one fish were added to each dish. Crustaceans and mummichog were exposed in sea water; guppies in pond water. After $1 \mathrm{~d}$, amphipods and fish were transferred to clean water in crystallization dishes $(100 \times 50 \mathrm{~mm})$ and exposure dishes examined to determine if all larvae had been eaten (they had). Crustaceans were maintained at $15^{\circ} \mathrm{C}$ and fish at $22^{\circ} \mathrm{C}$. Amphipods were fed pulverized trout chow and fish were fed tropical fish food flakes.

Experiments $\mathrm{D}$ and $\mathrm{E}$ exposed infected copepods to amphipods (D) and fish (E). Dozens of infected copepods (from Experiment A) were placed in filtered sea or pond water (as appropriate) in each of numerous Syracuse dishes and then four amphipods or one fish were added to each dish. At $1 \mathrm{~d}$, amphipods and fish were transferred to clean water and maintained as previously outlined; exposure dishes were examined to determine if all copepods had been eaten (they had). Experiment $\mathrm{F}$ involved exposure of fish to infected amphipods. Ten amphipods (from Experiment B, and presumed to contain larvae but not verifiable) were placed in filtered sea water in each of numerous Syracuse dishes and then one fish was added to each dish. At $1 \mathrm{~d}$, fish were transferred to clean water and maintained as previously outlined; exposure dishes were examined to determine if all amphipods had been eaten (they had).

At various times postexposure, crustaceans and fish were killed (via decapitation) and dissected in saline on microscope slides. Larvae from crustaceans and fish 20 or fewer days postinfection were fixed by adding an equal volume of $10 \%$ formalin to the saline; a petroleum-ringed coverglass was then placed over the mixture and larvae studied. Larvae from other fish were fixed in a hot solution of $5 \%$ glycerin $/ 70 \%$ alcohol and studied in glycerin. A microscope equipped with differential interference contrast lighting was used to study larvae.

\section{RESULTS}

\section{Hatching OF EGGS}

Larvae first emerged from eggs at $9 \mathrm{~d}$ in water at $20^{\circ} \mathrm{C}$ and at 11 or $17 \mathrm{~d}$ at $15^{\circ} \mathrm{C}$ (eggs from worms from two cormorants). At $10^{\circ} \mathrm{C}$, eggs had not embryonated by $40 \mathrm{~d}$ and were discarded. Eggs stored at $5{ }^{\circ} \mathrm{C}$ for 10 months did not embryonate after being moved to $20{ }^{\circ} \mathrm{C}$ for $15 \mathrm{~d}$ and the experiment was terminated.

\section{EXPERIMENTS A-F}

Experiment A: At 1-2 d postexposure, about half of the hundreds of copepods examined contained larvae (prevalence and intensity not precisely determined). Larvae were motile and generally free in the abdominal haemocoel where they were readily visible. Live, infected copepods were noticeably lethargic in comparison to copepods without larvae. Many infected copepods died within 2-3 d postinfection; larvae within them frequently remained motile for an additional $2 \mathrm{~d}$. Experiment B: One larva was found in one amphipod and none in 57 others (Table I).

Experiment C: Three of 6 guppies contained larvae (all motile), none of 27 mummichog did (Table I). At $20 \mathrm{~d}$ postinfection, larvae were within the intestinal wall. At 53 and $66 \mathrm{~d}$, they were in the abdominal cavity. Some of the latter were in a delicate, closely adherent "sleeve " of indeterminate nature resembling shed cuticle with a delicate fibrous texture (Table I). In addition, numerous host cells sometimes surrounded these "sleeves " or larvae by themselves, giving the appearance of a delicate capsule.

Experiment D: Five of nine amphipods contained larvae (all motile) (Table I).

Experiment E: Four of four mummichog contained larvae, as did six of seven guppies (Table I). All larvae were motile. Those in fish examined 10 or fewer days postinfection were in the intestinal wall. At later times (44-152 d), larvae were in the abdominal cavity, some free and others within "sleeves ", and some also surrounded by host cells (Table I).

Experiment F: Two of two mummichog contained larvae, as did two of seven guppies (Table I). All larvae were motile. Those in fish examined six or fewer days postinfection were in the intestinal wall and those in fish at 96 and $132 \mathrm{~d}$ were in the abdominal cavity. As in Experiment E, some larvae were within a "sleeve " and some free.

\section{DESCRIPTION OF SECOND-STAGE LARVAE RECENTLY EMERGED FROM EGGS}

Larvae (Fig. 1) emerging from eggs with retained, moulted cuticle forming loose, striated sheath slightly 
wider and quarter to half longer than larva within. Anterior extremity of sheath generally with several, irregularly digitiform extensions and larvae attaching, by way of anterior extremity, to bottoms of dishes and waving vigorously in medium. Posterior end of sheath attenuated and sharply pointed. At $15^{\circ} \mathrm{C}$, larvae remaining highly active for approximately $10 \mathrm{~d}$ after which becoming increasingly less motile, dying between 30 and $40 \mathrm{~d}$. Free-living, recently-emerged $(<24 \mathrm{hr})$ and $10 \mathrm{~d}$ old larvae: Long, slender (Table II), with striated cuticle.

\begin{tabular}{|c|c|c|c|c|}
\hline & $\begin{array}{l}\text { Days post- } \\
\text { exposure }\end{array}$ & $\begin{array}{l}\text { No. infected/ } \\
\text { No. exposed }\end{array}$ & $\begin{array}{l}\text { No. larvae } \\
\text { found }\end{array}$ & $\begin{array}{l}\text { Condition of host prior to dissection } \\
\text { and comments on location of larvae }\end{array}$ \\
\hline \multicolumn{5}{|l|}{ Experiment $\mathrm{B}^{a}$} \\
\hline amphipod & 3 & $1 / 1$ & 1 & amphipod live; larva in haemocoel \\
\hline amphipods & $2-33$ & $0 / 57$ & - & amphipods live \\
\hline \multicolumn{5}{|l|}{ Experiment $C^{b}$} \\
\hline mummichog & $1-12$ & $0 / 27$ & - & some fish live, some dead \\
\hline guppy & 20 & $1 / 1$ & 2 & fish dead; larvae in intestinal wall \\
\hline guppy & 34 & $0 / 1$ & - & fish dead \\
\hline guppy & 37 & $0 / 1$ & - & fish dead \\
\hline guppies & 53 & $1 / 2$ & 2 & $\begin{array}{l}\text { fish dead; larvae in abdominal cavity adjacent } \\
\text { to intestine within "sleeve "covered by host } \\
\text { cells }\end{array}$ \\
\hline guppy & 66 & $1 / 1$ & 1 & $\begin{array}{l}\text { fish live; larva in abdominal cavity with a few } \\
\text { adherent host cells but not within a "sleeve" }\end{array}$ \\
\hline \multicolumn{5}{|l|}{ Experiment $\mathrm{D}^{c}$} \\
\hline amphipods & 3 & $2 / 2$ & 1,6 & amphipod live; larvae in haemocoel \\
\hline amphipods & 14 & $1 / 5$ & 1 & amphipod live; larva in haemocoel \\
\hline amphipod & 22 & $1 / 1$ & 5 & amphipod live; larvae in haemocoel \\
\hline amphipod & 33 & $1 / 1$ & 1 & amphipod live; larva in haemocoel \\
\hline \multicolumn{5}{|l|}{ Experiment $\mathrm{E}^{d}$} \\
\hline mummichog & 4 & $1 / 1$ & 41 & fish moribund; larvae in intestinal wall \\
\hline mummichog & 5 & $1 / 1$ & $>100$ & fish dead; larvae in intestinal wall \\
\hline mummichog & 8 & $1 / 1$ & 112 & fish dead; larvae in intestinal wall \\
\hline mummichog & 10 & $1 / 1$ & 70 & fish dead; larvae in intestinal wall \\
\hline guppy & 44 & $1 / 1$ & 10 & $\begin{array}{l}\text { fish dead; larvae within fat around } \\
\text { intestine (presence or absence of " sleeve " not } \\
\text { determined) }\end{array}$ \\
\hline guppy & 45 & $1 / 1$ & 5 & $\begin{array}{l}\text { fish dead; larvae within abdominal cavity, one } \\
\text { within "sleeve " and four free }\end{array}$ \\
\hline guppies & 87 & $2 / 2$ & 3,10 & $\begin{array}{l}\text { one fish live, one dead; larvae either covered } \\
\text { in host cells or within "sleeve" }\end{array}$ \\
\hline guppy & 112 & $1 / 1$ & 1 & fish dead; larva free within fat around intestine \\
\hline guppies & 152 & $1 / 2$ & 19 & $\begin{array}{l}\text { fish live; larvae free within fat around } \\
\text { intestine and free in abdominal cavity }\end{array}$ \\
\hline \multicolumn{5}{|l|}{ Experiment $\mathrm{F}^{e}$} \\
\hline mummichog & 3 & $1 / 1$ & 1 & fish dead; larva in intestinal wall \\
\hline mummichog & 6 & $1 / 1$ & 16 & fish dead; larvae in intestinal wall \\
\hline guppy & 56 & $0 / 1$ & - & fish dead \\
\hline guppies & 76 & $0 / 2$ & - & one fish live, one dead \\
\hline guppy & 86 & $0 / 1$ & - & fish dead \\
\hline guppies & 96 & $1 / 2$ & 2 & $\begin{array}{l}\text { fish live; larvae within "sleeve "with attached } \\
\text { host cells within fat around intestine }\end{array}$ \\
\hline guppy & 132 & $1 / 1$ & 1 & $\begin{array}{l}\text { fish live; larva within mesentery and observed } \\
\text { to pull itself free of "sleeve " when placed in } \\
\text { saline }\end{array}$ \\
\hline
\end{tabular}

${ }^{a}$ Experiment B, amphipods exposed directly to recently-emerged, second-stage larvae.

${ }^{b}$ Experiment C, mummichog and guppies exposed directly to recently-emerged, second-stage larvae.

${ }^{c}$ Experiment D, amphipods exposed to copepods containing second-stage larvae.

${ }^{d}$ Experiment E, mummichog and guppies exposed to copepods containing second-stage larvae.

${ }^{e}$ Experiment $\mathrm{F}$, mummichog and guppies exposed to amphipods presumed to contain second-stage larvae.

$f$ " sleeve " = closely adhering, sleeve-like structure resembling cuticle and often with fibrous texture.

Note: Larvae at 20 or fewer days in second stage; larvae at 44 or more days in third stage.

Table I. - Numbers of amphipods (Gammarus sp.) and fish (mummichog, Fundulus beteroclitus; guppies, Lebistes reticulatus) infected with larvae of Contracaecum rudolphii at different times after exposure to larvae in different experiments (B-F); numbers and locations of larvae and condition of fish also indicated. 
Prominent, hyalinized, cuticular tooth present on cephalic surface ventral to oral opening. Oral opening leading into tube of hyalinized cuticle; latter generally more dilated for anteriormost $5 \mu \mathrm{m}$ than remainder of length. Cuticular tube continuing posteriorly and appearing to lack immediately adjacent tissue for

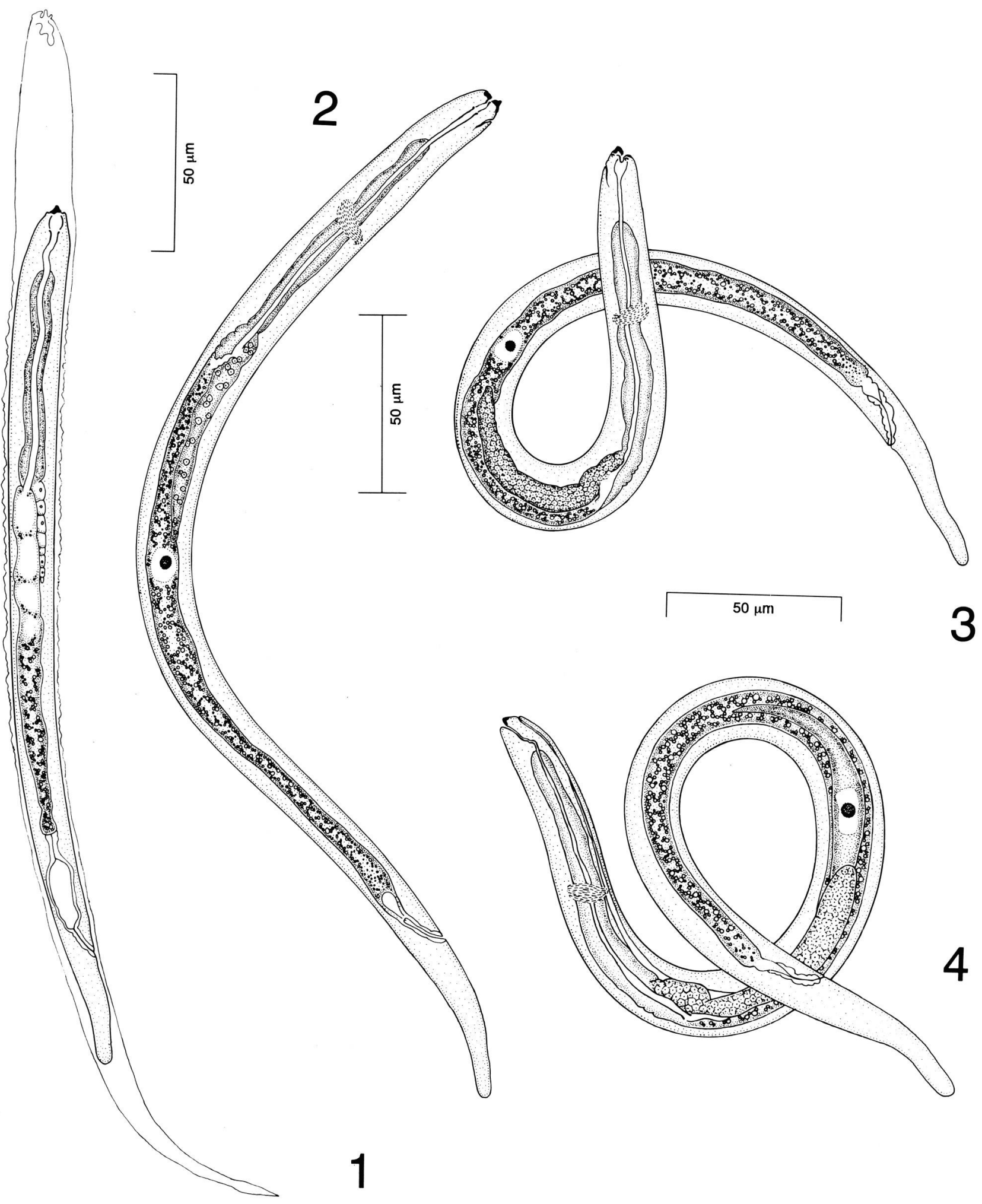

Figs. 1-4. - Contracaecum rudolphii, second-stage larvae (free-living, from copepods (Tigriopus sp.), and from amphipods (Gammarus sp.)). Fig. 1. Larva recently emerged from egg. Fig. 2. Larva from copepod $42 \mathrm{hr}$ postexposure. Figs. 3, 4. Larvae from amphipods exposed to infected copepods 14 and $22 \mathrm{~d}$ previously, respectively. 
approximately $15-20 \mu \mathrm{m}$ before becoming surrounded by delicate, thin wall; together these comprising oesophagus. Presumptive ventriculus marked by slight increase in width of wall at posterior end of oesophagus. Ventricular-intestinal junction readily apparent. Presumptive ventricular appendix present as delicate column of narrow cells adjacent to ventral side of anteriormost intestine and extending posteriorly for average of $77 \mu \mathrm{m}$ at $24 \mathrm{hr}$ and $84 \mu \mathrm{m}$ at $10 \mathrm{~d}$. Presumptive intestinal caecum not distinguishable. Intestine generally containing large clear areas in anterior third and small, round, brown particles throughout remainder. Short, narrow constriction joining intestine to rectum. Rectum joined by narrow canal to anus. Nervous and excretory systems not discernable. Posterior end of larva digitiform with bluntly rounded extremity.

\section{DESCRIPTIONS OF SECOND-STAGE LARVAE FROM CRUSTACEANS}

Larvae from copepods (Fig. 2): Larvae $42 \mathrm{hr}$ postexposure (Experiment A) wider and longer than recentlyemerged larvae (Table II). Other characteristics: cuticle delicately striated; excretory pore visible on cephalic surface ventral to cuticularized tooth; oesophageal wall and ventriculus more apparent than in recentlyemerged larvae; ventricular appendix digitiform, extending posteriorly for an average of $102 \mu \mathrm{m}$ from ventricular-intestinal junction and containing several small, scattered cells; presumptive intestinal caecum marked by small swelling anterior to ventricular appendix and latter containing few small, scattered cells; nerve ring apparent at approximately mid length of oesophagus; prominent cell with large nucleus present in pseudocoelom slightly posterior to tip of ventricular appendix and not appearing associated with any other structure (although presumably cell of excretory gland).

Larvae from amphipods: Larva $3 \mathrm{~d}$ postexposure (Table I, Experiment B) similar in length and width (Table II) and morphologically to larvae from copepods. Larvae 14 and 22 d postexposure (Table I, Experiment D) similar in length and width to larvae from copepods (Table II) but differing slightly as follows: oesophagus and ventriculus more apparent; ventricular appendix and presumptive intestinal caecum slightly larger and packed with small cells with inconspicuous borders; in larva at $14 \mathrm{~d}$ (Fig. 3), cell with large nucleus present in pseudocoelom posterior to tip of ventricular appendix but appearing not associated with any other structure; in larva at $22 \mathrm{~d}$ (Fig. 4), this cell associated with excretory gland of excretory system.

\section{DESCRIPTIONS OF LARVAE FROM FISH}

At 8 d, larvae (from mummichog; Table I, Experiment E) similar in size and morphology (Fig. 5) and slightly longer and wider than recently-emerged larvae or larvae from crustaceans (Table II). Other differences including: cuticle thin with delicate transverse striations; intestinal caecum apparent as tiny anterior projection from ventricular-intestinal junction; ventricular appendix slightly longer and containing, in posterior third, large cell with prominent nucleus; intestinal wall containing small round cells.

\begin{tabular}{|c|c|c|c|c|c|c|c|c|c|}
\hline & $\begin{array}{c}\text { Second- } \\
\text { stage } \\
\text { larvae } \\
24 \mathrm{hr} \\
\text { after } \\
\text { emergence } \\
\text { from eggs }\end{array}$ & $\begin{array}{c}\text { Second- } \\
\text { stage } \\
\text { larvae }^{a} \\
10 \mathrm{~d} \\
\text { after } \\
\text { emergence } \\
\text { from eggs }\end{array}$ & $\begin{array}{l}\text { Second } \\
\text { stage- } \\
\text { larvae } \\
42 \mathrm{hr} \\
\text { in copepods } \\
\text { (Experiment A) }\end{array}$ & $\begin{array}{c}\text { Second } \\
\text { stage } \\
\text { larvae } \\
3 \mathrm{~d} \\
\text { in amphipod } \\
\text { (Experiment } \mathrm{B} \text { ) }\end{array}$ & $\begin{array}{c}\text { Second- } \\
\text { stage } \\
\text { larvae } 14 \\
\& 22 \mathrm{~d} \\
\text { in amphipod } \\
\text { (Experiment D) }\end{array}$ & $\begin{array}{c}\text { Second- } \\
\text { stage } \\
\text { larva } \\
8 \mathrm{~d} \\
\text { in mummichog } \\
\text { (Experiment E) }\end{array}$ & $\begin{array}{c}\text { Third- } \\
\text { stage } \\
\text { larva } \\
45 \mathrm{~d} \\
\text { in guppy } \\
\text { (Experiment E) }\end{array}$ & $\begin{array}{c}\text { Third- } \\
\text { stage } \\
\text { larva } \\
53 \mathrm{~d} \\
\text { in guppy } \\
\text { (Experiment E) }\end{array}$ & $\begin{array}{c}\text { Third-stage } \\
\text { larva } \\
66 \mathrm{~d} \\
\text { in guppy } \\
\text { (Experiment C) }\end{array}$ \\
\hline $\mathrm{N}$ & 10 & 10 & 12 & 1 & 1,1 & 10 & 1 & 1 & 1 \\
\hline Total length & $\begin{array}{c}238 \\
(223-255)\end{array}$ & $\begin{array}{c}245 \\
(215-285)\end{array}$ & $\begin{array}{c}365 \\
(318-417)\end{array}$ & 310 & 340,385 & $\begin{array}{c}407 \\
(370-470)\end{array}$ & 860 & 1,600 & 2,700 \\
\hline $\begin{array}{l}\text { Maximum } \\
\text { width }\end{array}$ & $\begin{array}{c}14 \\
(13-15)\end{array}$ & $\begin{array}{c}14 \\
(13-15)\end{array}$ & $\begin{array}{c}17 \\
(13-20)\end{array}$ & 17 & 17,18 & $\begin{array}{c}19 \\
(18-22)\end{array}$ & 35 & 70 & 110 \\
\hline Nerve ring & - & - & $52(32-64)$ & 53 &,- 55 & $54(45-63)$ & 100 & 110 & 140 \\
\hline $\begin{array}{l}\text { Length oeso- } \\
\text { phagus }\end{array}$ & $\begin{array}{c}77 \\
(75-85)\end{array}$ & $\begin{array}{c}84 \\
(75-90)\end{array}$ & $\begin{array}{c}102 \\
\left(92-118^{\mathrm{b}}\right)\end{array}$ & $\underline{1}^{100}$ & 83,85 & $98(90-110)$ & 142 & 260 & 310 \\
\hline $\begin{array}{l}\text { Length } \\
\text { ventriculus }\end{array}$ & - & - & c & 13 & 15,15 & $16(12-21)$ & 30 & 20 & 20 \\
\hline $\begin{array}{l}\text { Length ventr. } \\
\text { appendix }\end{array}$ & $\begin{array}{c}35 \\
(25-53)\end{array}$ & $26(20-33)$ & - & 50 & 53,60 & $72(57-93)$ & 140 & 240 & 260 \\
\hline $\begin{array}{l}\text { Length intes- } \\
\text { tinal caecum }\end{array}$ & - & - & - & - &,-- & - & 40 & 120 & 140 \\
\hline Excretory cell & - & - & - & 165 & 160,180 & $\begin{array}{c}198 \\
(180-220)\end{array}$ & 400 & 680 & 1,150 \\
\hline Anus & $23(22-25)$ & - & $49(44-54)$ & 25 & 40,47 & $35(27-45)$ & 54 & 70 & 110 \\
\hline
\end{tabular}

a free-living.

${ }^{b}$ includes ventriculus.

included in length of oesophagus.

Table II. - Morphometrics of larvae of Contracaecum rudolphii at various times after emergence from eggs or postinfection in copepods (Tigriopus sp.), amphipods (Gammarus sp.), or fish (guppies, Lebistes reticulatus; mummichog, Fundulus heteroclitus). 


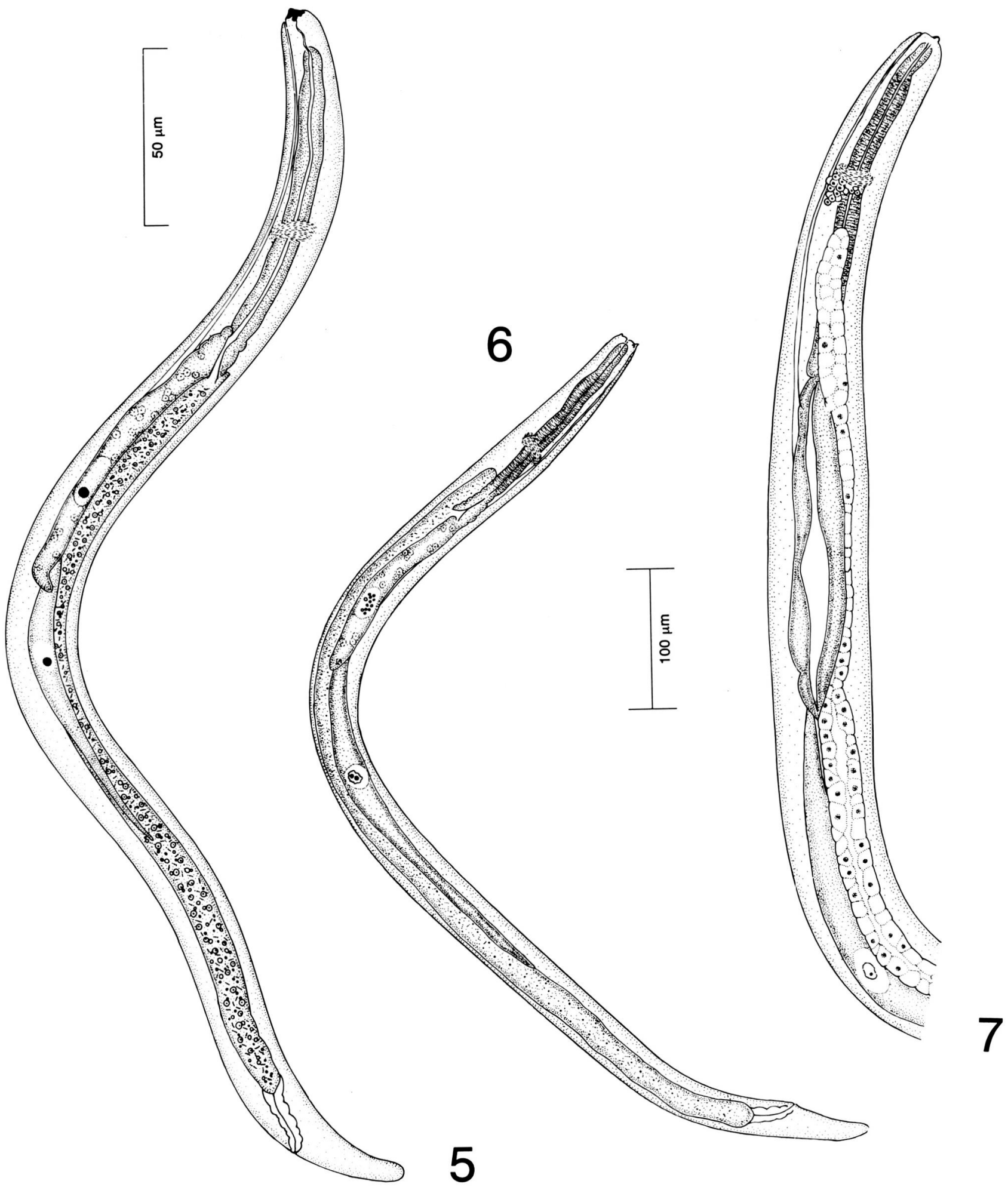

Figs. 5-7 - Contracaecum rudolphii, larvae from fish (mummichog, Fundulus beteroclitus; guppies, Lebistes reticulatus). Fig; 5 . Larva from mummichog $8 \mathrm{~d}$ postinfection. Fig. 6. Larva from guppy $45 \mathrm{~d}$ postinfection. Fig. 7. Larva from guppy $53 \mathrm{~d}$ postinfection.

At $20 \mathrm{~d}$, larvae (from guppy; Table I, Experiment C) slightly contracted in appearance but otherwise similar to larvae at $8 \mathrm{~d}$.
At $45 \mathrm{~d}$, larva (from guppy; Table I, Experiment E; Fig. 6) slightly longer and wider than larvae at $8 \mathrm{~d}$ (Table II). Other differences including: cuticle with pro- 
minent transverse and delicate longitudinal striations; cephalic extremity with four prominent papillae; narrow, non-striated wall of tissue surrounding tube of hyalinized cuticle immediately posterior to buccal region (an area previously lacking visible tissue wall); intestinal caecum extending halfway to nerve ring; large cell in ventricular appendix containing numerous round bodies (rather than nucleus); nucleus of cell of excretory gland with irregular margin and containing two round bodies. Larva not within "sleeve".

At $53 \mathrm{~d}$, larva (from guppy; Table I, Experiment C; Fig. 7) about twice as long and wide as larva at $45 \mathrm{~d}$ (Table II). Other differences including: lumen apparent within ventricular appendix; intestinal caecum and intestinal wall containing faintly defined, large cells. Larva within "sleeve ".

At $66 \mathrm{~d}$, larva (from guppy; Table I, Experiment C) considerably longer and wider than larva at $53 \mathrm{~d}$ (Table II), but otherwise similar to it. Larva not within " sleeve".

At 87 d, larvae (from guppy; Table I, Experiment E) varying in length and width (Table III). Genital primordium in longer larvae $(\geq 2 \mathrm{~mm})$ visible as single cell between ventral hypodermis and excretory gland at approximately mid length of body. Larvae otherwise similar to larva at $53 \mathrm{~d}$. Some larvae within "sleeve " and some not.

At $112 \mathrm{~d}$, larva (from guppy; Table I, Experiment E) $1150 \mu \mathrm{m}$ long, $40 \mu \mathrm{m}$ wide, and similar to larva at $53 \mathrm{~d}$. Larva not within "sleeve".

At 132 d, larva (from guppy; Table I, Experiment F) $2750 \mu \mathrm{m}$ long, $90 \mu \mathrm{m}$ wide, and similar to long larvae at $86 \mathrm{~d}$. Larva within "sleeve".

At 152 d, larvae (from guppy; Table I, Experiment E; Figs. 8-11) varying in length and width. Five largest larvae (Table III) longer and wider than larvae at all previous times but otherwise similar to larvae at $86 \mathrm{~d}$. Larvae not within "sleeve".

\section{DISCUSSION}

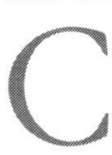

hanges in C. rudolphii while in the copepod (Tigriopus sp.) primarily involved body size and development of the ventricular appendix (from a delicate column of narrow cells to a longer, digitiform structure containing several small, scattered cells) and the excretory system (from unapparent to a prominent cell with a large nucleus). Huizinga (1966) reported a similar slight increase in size of larvae in the copepod Tigriopus californicus (as well as unexplained " partial development ") but " no morphological change "in Cyclops vernalis. The present study considers the changes that occurred in the parasite while in the copepod to be developmentally significant; they were associated with markedly increased success by the parasite in establishing in its fish host (10 of 11 fish exposed to copepods harbouring larvae became infected versus none of 27 mummichog and 3 of 6 guppies exposed directly to recently-emerged larvae). Huizinga (1966) reported no (0 of 25) to limited (4 of 25) success in infecting guppies with T. californicus and C. vernalis harbouring larvae, respectively, and considerable success ( 3 of 5 ) in infecting mummichog (= killifish) with T. californicus harbouring larvae.

Amphipods, in addition to copepods, were found capable of transporting larvae of C. rudolphii to fish, something not previously reported for the species. Successful infections in amphipods were generally established only when amphipods ate copepods containing larvae ( 5 of 9 became infected), however, and not when amphipods ate free-living, second-stage larvae in water ( 1 of 58 became infected although all larvae were consumed). This requirement of larvae to pass through copepods before being infective to amphipods is strikingly similar to that noted for infectivity of larvae to fish and supports the suggestion that the

\begin{tabular}{|c|c|c|c|c|c|c|c|c|c|c|c|}
\hline & \multicolumn{10}{|c|}{ Larvae $87 d$} & \multirow{2}{*}{$\begin{array}{c}\text { Larvae } \\
152 \mathrm{~d} \\
(\mathrm{~N}=5)\end{array}$} \\
\hline & $\# 1$ & $\# 2$ & $\# 3$ & $\# 4$ & $\# 5$ & \#6 & $\# 7$ & $\# 8$ & $\# 9$ & $\# 10$ & \\
\hline Total length (mm) & 0.8 & 1.1 & 1.5 & 1.8 & 1.9 & 2.0 & 2.2 & 2.5 & 2.7 & 2.9 & $3.5(3.1-3.9)$ \\
\hline Maximum width & 30 & 35 & 50 & 60 & 65 & 70 & 85 & 90 & 95 & 90 & $114(110-120)$ \\
\hline Nerve ring & 60 & - & - & 130 & 110 & - & 130 & 150 & 140 & 140 & $167(150-200)$ \\
\hline L. oesoph. & 165 & - & - & 230 & 200 & 210 & - & 370 & 340 & 310 & $391(370-415)$ \\
\hline L. ventr. & 15 & - & - & 20 & 25 & 20 & - & 30 & 20 & 30 & $29(25-30)$ \\
\hline L. ventr. app. & 130 & - & - & 210 & 220 & 220 & - & 325 & 270 & 350 & $359(320-380)$ \\
\hline L. int. caecum & 40 & - & - & 80 & 90 & 80 & - & 190 & 150 & 150 & $191(170-225)$ \\
\hline Excr. cell $(\mathrm{mm})$ & - & - & - & 0.6 & 0.7 & - & - & 0.9 & 0.9 & 1.0 & $1.2(1.1-1.3)$ \\
\hline Anus & - & 50 & 65 & 60 & 65 & 60 & 65 & 75 & 85 & 85 & $88(85-90)$ \\
\hline
\end{tabular}

Table III. - Morphometrics (in $\mu \mathrm{m}$, unless otherwise specified) of third-stage larvae of Contracaecum rudolphii in guppies (Lebistes reticulatus) 87 and $152 \mathrm{~d}$ after ingesting copepods (Tigriopus sp.) containing second-stage larvae. Note: Ten larvae of considerable size range were recovered at $86 \mathrm{~d}$ and five larvae of more similar size at $152 \mathrm{~d}$. 


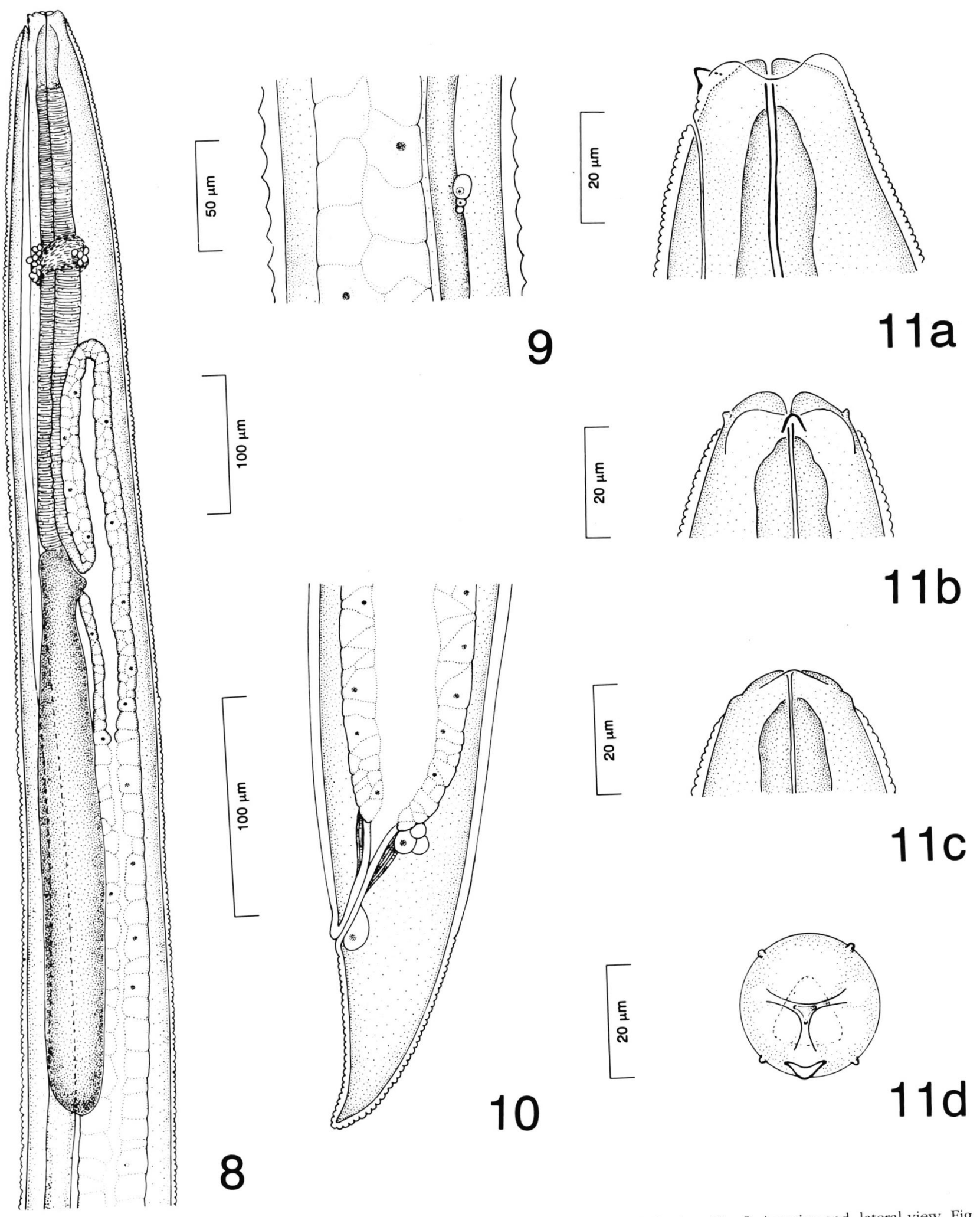

Figs. 8-11. - Contracaecum rudolphii, larva from guppy (Lebistes reticulatus) $152 \mathrm{~d}$ postinfection. Fig. 8. Anterior end, lateral view. Fig. 9. Genital primordium, lateral view. Fig. 10. Tail, lateral view. Figs. 11 A-D. Anterior extremity, lateral, ventral, dorsal, and en face views, respectively. 
copepod serves a partial developmental role in the transmission of C. rudolphii. Within the genus Contracaecum, the copepod is reported to serve different roles in transmission ranging from that suggested herein for $C$. rudolphii (i.e., a "precursor " role, see below) to being the site of a moult (e.g. C. micropapillatum (Stossich, 1850)) (see Anderson 1992). Extreme plasticity also apparently characterizes Pseudoterranova decipiens (Krabbe, 1878) where a moult has been suggested in macrocrustaceans (McClelland, 1990).

The amphipod is considered herein a paratenic host of $C$. rudolphii. Amphipods have also been reported to harbour larval C. micropapillatum although, in contrast to the present study, infections were said to have been acquired when amphipods ate free-living larvae (Anderson, 1992). Pseudoterranova decipiens can also pass in the food chain from one crustacean host to a second (" serial transmission ") and acquisition by amphipods is, as in the present study, much more efficient when a copepod is initially involved (McClelland, 1990). Copepods serving this role have previously been termed " precursor " hosts (note: other authors may use the term "metaparatenic host " (see Odening, 1976)) and consumption of them by macroinvertebrates likely explains the presence, in the latter, of larvae of various species of marine and freshwater ascaridoids (Overstreet, 1983; McClelland, 1990). It would be informative to know whether morphogenesis occurs in these parasites in the copepod, similar to that noted herein.

When copepods are involved in a life cycle, it probably is advantageous for the parasite to use a subsequent paratenic host (macroinvertebrate) or be quickly transmitted to fish. Copepods harbouring C. rudolphii are adversely affected by the presence of larvae, becoming lethargic or moribund or dying within a few days of infection (Huizinga 1966; present study), as do copepods harbouring other ascaridoid larvae (McClelland, 1990). Affected copepods in the present study were readily fed upon by amphipods. In nature, transmission likely involves copepods which acquire larvae from the free-living environment and are then fed upon by paratenic hosts or fish. McClelland (1990) reported altered behaviour in amphipods harbouring larvae of $P$. decipiens; the limited observations herein precluded conclusions.

Huizinga (1966) suggested that at $18 \mathrm{~d}$ postinfection in fish, " a moult (of C. mudolphii) was in progress " although " larvae did not shed the second-stage cuticle while encapsulated, but retained it as a closely adhering layer. "In the present study, larvae at $20 \mathrm{~d}$ did not appear to be moulting. However, observations at later times support Huizinga (1966); at $45 \mathrm{~d}$ and later times many larvae were within a closely adherent "sleeve " resembling cuticle. In addition, larvae were sometimes surrounded by host cells, giving the appearance of a delicate capsule. Onset of a moult may be associated with migration of larvae from the intestinal wall (their site 20 or fewer days postinfection) to the abdominal cavity (their site 44 or more days postinfection). Huizinga (1966) recovered larvae in fish at times earlier than $18 \mathrm{~d}$ postinfection by using a pepsin digest and thus did not know their specific locations; his larvae at $18 \mathrm{~d}$ were " encapsulated along the intestinal mesenteries ".

In the present study, third-stage larvae continued to grow in length, with the longest $(3.9 \mathrm{~mm})$ having been obtained from the fish with the oldest (152 d) infection. Different larvae in a given fish were sometimes of different lengths, however (e.g. at $87 \mathrm{~d}$, Table III), suggesting that growth is asynchronous. Huizinga (1966) also noted the longest $(1.4 \mathrm{~mm})$ larva came the fish with the oldest (37 d) infection; Moravec (1994) stated that " advanced " third-stage larvae ranged from 15-24 mm. McClelland and Ronald (1974b) indicated that second-stage $C$. osculatum Rudolphi, 1802 grew continuously for 32 weeks in cultures at $15^{\circ} \mathrm{C}$ but commenced to moult to the subadult (fourth) stage when the temperature was raised to $35^{\circ} \mathrm{C}$. McClelland and Ronald (1974a, 1974b) found a similar phenomenon, namely development from the second to the fourth stage with only one intervening moult, in cultured $P$. decipiens.

The detailed description of larvae of C. rudolphii provided herein will help facilitate identification of anisakid larvae in invertebrates and fish (also, see Moravec 1994). In addition to Huizinga (1966), the life cycle of the Contracaecum sp. in cormorants has previously been studied by Thomas (1937a, b, 1940), Dubinin (1949), and Mozgovoy et al. (1965, 1968). However, within the genus Contracaecum as a whole, only the development of $C$. osculatum has previously been studied in a manner as detailed as that presented herein for $C$. rudolphii. The study of C. osculatum was done with cultured specimens; its $450 \mu \mathrm{m}$ long, second stage has a large nucleus in the ventricular appendix, a readily distinguishable excretory system, and a genital primordium (McClelland and Ronald, 1974b, Fig. 3) not seen in second-stage C. rudolphii from crustaceans. Cephalic structures of third stage C. rudolphii from fish at $152 \mathrm{~d}$ postinfection were basically similar to those of $6 \mathrm{~mm}$ long, cultivated larvae of C. osculatum (see McClelland and Ronald $1974 b$; Figs. 1, 2) although the lips were not as prominent and the amphids not visible. They also resembled the cephalic structures of secondstage larvae of $P$. decipiens (see McClelland and Ronald, 1974a; Fig. 1), Anisakis simplex (Rudolphi, 1809) (see Smith, 1983; Plate 1, Figs. $a, b, e)$, and Raphidascaris acus (Bloch, 1779) (see Smith 1984; Fig. 5). 
Anderson and Bartlett (1993) suggested that precocity may be widespread but unrecognized among many nematodes, especially those that exhibit plasticity in transmission. None of the four ways proposed by Anderson (1992) as manifestations of precocity was observed in C. rudolphii. Indeed, its single-celled genital primordium was first visible in larvae at $86 \mathrm{~d}$ in fish and it remained unchanged in the oldest larvae. The single-celled genital primordium in C. osculatum only grew after larvae moulted to the fourth stage (McClelland and Ronald, 1974 b). Contracaecum rudolphii is rather unusual, however, in that growth of some larvae apparently continues while what is presumed to be cuticle from an earlier moult is retained. McClelland and Ronald (1974a, 1974b) suggested somewhat similar developments in cultured $C$. osculatum and $P$. decipiens to be neoteny or artifact.

\section{ACKNOWLEDGEMENTS}

T he author gratefully thanks Basma Kavanagh who prepared the illustrations and helped dissect nematodes, Rod Beresford who also helped dissect nematodes and examine cormorants, Dr John Roff (University of Guelph) who identified copepods, Dr Bev Scott (Huntsman Marine Lab) who identified larval fish, Trevor Wilkie and Dave Harris (Nova Scotia Department of Natural Resources) who helped collect cormorants, Bernie MacLennan (University College of Cape Breton) who provided considerable technical support, and Dr Roy Anderson (University of Guelph) who read drafts. This study was supported by grants from the Natural Sciences and Engineering Research Council of Canada and the University College of Cape Breton.

\section{REFERENCES}

Anderson R.C. Nematode parasites of vertebrates, their development and transmission. CAB International, Wallingford, U.K., 1992.

Anderson R.C. \& BARTLETT C.M. The significance of precocity in the transmission of the nematode parasites of vertebrates. Canadian Journal of Zoology, 1993, 71, 1917-1922.

Dubinin V.B. Experimental study of the life cycles of some parasitic worms of animals in the Volga River delta. Parasitologicheskii Sbornik, Zool. Inst. Akademiya Nauk SSSR, 1949, 11, 126-160 (in Russian).

Hutzinga H.W. Studies on the life cycle and development of Contracaecum spiculigerum (Rudolphi, 1809) (Ascaridoidea: Heterocheilidae) from marine piscivorous birds. Journal of the Elisha Mitchell Scientific Society, 1966, 82, 181-195.

Køie M. \& Fagerholm H.-P. Third-stage larvae emerge from eggs of Contracaecum osculatum (Nematoda, Anisakidae). Journal of Parasitology, 1993, 79, 777-780.

McClelland G. Larval sealworm (Pseudoterranova decipiens) infections in benthic macrofauna. Canadian Bulletin of Fisheries and Aquatic Sciences, 1990, 222, 47-65.

McClelland G. \& Ronald K. In vitro development of Terranova decipiens (Nematoda) (Krabbe, 1878). Canadian Journal of Zoology, 1974a, 52, 471-479.

McClelland G. \& Ronald K. In vitro development of the nematode Contracaecum osculatum Rudolphi 1802 (Nematoda: Anisakinae). Canadian Journal of Zoology, $1974 b, 52,847-855$.

Measures L.N. \& Hong H. The number of moults in the egg of sealworm, Pseudoterranova decipiens (Nematoda: Ascaridoidea): an ultrastructural study. Canadian Journal of Fisheries and Aquatic Sciences, 1995, 52 (suppl. 1), 156160.

Moravec F. Parasitic nematodes of freshwater fishes of Europe. Academia, Praha, 1994.

Mosgovoy A.A., Shakhmatova V.I. \& Semenova M.K. Study of the life cycle of Contracaecum spiculigerum (Ascaridata: Anisakidae), a nematode of fish-eating birds. Mater. nauch. konf. Vvesoiuz Obshch. Gel'mint., 1965, Pt. 4., 169-174. (in Russian).

Mosgovoy A.A., Shakhmatova V.I. \& Semenova M.K. Life cycle of Contracaecum spiculigerum (Ascaridata: Anisakidae), a parasite of domestic and game birds. Trudy Gel'mintologicheskoi Laboratorii. Akademiya Nauk, 1968, 19, 129-136 (in Russian).

ODEnING K. Conception and terminology of hosts in parasitology, in: Advances in Parasitology, Vol 14. Dawes B. (ed), London, 1976, 1-93.

OverstreEt R.M. Metazoan symbionts of crustaceans, in : The biology of Crustacea, Vol. 6, Chap. 4. Bliss D.E. (ed.), Academic Press, New York, 1983, 155-250.

SMITH J.D. Development of Raphidascaris acus (Nematoda, Anisakidae) in paratenic, intermediate, and definitive hosts. Canadian Journal of Zoology, 1984, 62, 1378-1386.

SмITH J.W. Anisakis simplex (Rudolphi, 1809, det. Krabbe, 1878) (Nematoda: Ascaridoidea): morphology and morphometry of larvae from euphausiids and fish, and a review of the life history and ecology. Journal of Helminthology, 1983, 57, 205-224.

Thomas L.J. On the life cycle of Contracaecum spiculigerum (Rud.). Journal of Parasitology, 1937a, 23, 429-431.

Thomas L.J. Further studies on the life cycle of Contracaecum spiculigerum. Journal of Parasitology, 1937 b, 23, 572 .

Thomas L.J. Life cycle studies on Contracaecum spiculigerum, a nematode from the cormorant, Phalacrocorax auritus and other fish-eating birds (Abstract). Report of Proceedings of the International Congress (3rd) for Microbiology, New York, 1940, 11, 883.

Reçu le 7 juin 1996 Accepté le 8 août 1996 